"Functional Finance, New Classical Economics and Great Great Grandsons"

by

David Colander

July, 2002

MIDDLEBURY COLLEGE ECONOMICS DISCUSSION PAPER NO. 02-34

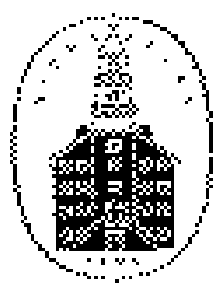

DEPARTMENT OF ECONOMICS

MIDDLEBURY COLLEGE

MIDDLEBURY, VERMONT 05753

http://www.middlebury.edu/ econ 


\title{
Functional finance, new classical economics and great great grandsons
}

\author{
by David Colander
}

At sea Septr. 1944.

My dear Lerner,

Your book arrived in London whilst I was away at Bretton Woods. But now again I am on the sea for yet another visit to the U.S.A., and the sea voyage has given me an opportunity to read it.

It is a grand book worthy of one's hopes of you. A most powerful piece of well organized analysis with high aesthetic qualities, though written more perhaps than you see yourself for the cognoscenti in the temple and not for those at the gate. Anyhow I prefer it for intellectual enjoyment to any recent attempts in this vein.

In the second of the two books which you have placed within one cover, I have marked with particular satisfaction and profit three pairs of chapters - chap 20 and 21, chap 24 and 25, and chap 28 and 29. Here is the kernel of yourself. It is very original and grand stuff. I shall have to try when I get back to hold a seminar for the heads of the Treasury on Functional Finance. It will be very hard going-I think I shall ask them to let me hold a seminar of their sons instead, agreeing beforehand that, if I can convince the boys, they will take it from me that it is so! ${ }^{1}$

The above letter from John Maynard Keynes to Abba Lerner celebrating his book The Economics of Control contains the essence of my view of functional finance: It is grand stuff, worthy of much more serious attention than it currently receives.

The generation before me - the sons whom Keynes spoke of - knew it was grand stuff, but their sons - my generation and their grandsons - began to lose the vision. It is now fair to say that their great grandsons have come full circle-back to where the heads of Treasury were in the 1930s, and I sometimes wonder whether they might not be even a little bit behind that. In reading the economics journals and talking with newly-minted $\mathrm{PhDs}$, it is as if Keynesian economics never existed.

There are two exceptions to this blanket observation. The first concerns policy makers. While most policy makers now tell a Classical story, their practice still reflects many of the ideas of functional finance; the expectation of government intervention is still giving stability to the economy and allowing policy makers talk to be stronger than their actions. The second exception is in cutting-edge macro economic theory. The new work on multiple equilibria macro, selection mechanisms and complex dynamics is beginning to touch on ideas that can once again make functional finance relevant. When 
that work has progressed and diffused through the profession, I believe the profession will see once again why functional finance is grand stuff.

In this paper I will try to shed some light on why functional finance fell out of favor, and why, I believe, it will come back into its own as the recent developments of modern macro theory progress a bit further. Specifically I will argue that the rules of functional finance, as developed by Lerner, are fully consistent with assumptions of rational expectations placed in a context of a realistic economy and that, theoretically, the rules of functional finance are as relevant now as they were when Lerner first developed them in the 1940s. There are limitations, some serious, about their use in practice, but when supplemented by an inflation rule and seen as a general structural guide to macro policy, they are a good first step and worthy of being a focal point in the teaching of macroeconomics.

The rules of Functional Finance

I will first specify what functional finance is. 'Functional finance' is the name given by Lerner to the theory of financing government according to the following three rules:

1. The government shall maintain a reasonable level of demand at all times. If there is too little spending and, thus, excessive unemployment, the government shall reduce taxes or increase its own spending. If there is too much spending, the government shall prevent inflation by reducing its own expenditures or by increasing taxes.

2. By borrowing money when it wishes to raise the rate of interest and by lending money or repaying debt when it wishes to lower the rate of interest, the government shall maintain that rate of interest that induces the optimum amount of investment.

3. If either of the first two rules conflicts with the principles of 'sound finance' or of balancing the budget, or of limiting the national debt, so much the worse for these principles. The government press shall print any money that may be needed to carry out rules 1 and 2 .

In proposing these rules of functional finance Lerner's purpose was to shift thinking about government finance from principles of sound finance that make sense for individuals - such as a balanced budget - to sound finance principles (now designated as functional finance) that make sense for the aggregate economy in which government spending and taxing decisions affect levels of economic activity. These two differed because the secondary effects of spending decisions and savings decisions - what Lerner and I called macro externalities - had to be taken into account in the aggregate economy. By introducing functional finance Lerner's goal was to get economists to focus on the consequences of government financing, not on the then generally accepted, but little considered, rules of sound finance and the quantity theory of money.

Lerner's stark presentation of these rules of functional finance caused much stir in the 1940s and 1950s when most Keynesians, including Keynes, were politically more circumspect about Keynesian ideas for government fiscal policy than they were in the 1960s. Thus the letter quoted above was written, in part, to atone for a tongue-lashing that Keynes had given Lerner at a Federal Reserve seminar for saying that deficits did not matter, a comment that caused Evsey Domar to lean over to Lerner and say that Keynes should read The General Theory. 
Through the debates over functional finance, (and Lerner's ability to win them), the concept of functional finance became well known. In the 1950s and 1960s, Lerner's functional finance rules became both the basis of most textbook presentations of Keynesian economics and the basis for policy. Thus when Keynesian policy came under fire in the late 1960s and early 1970s, it was Lerner's functional finance that most people were attacking. ${ }^{2}$ That fire intensified through the 1970s, became a full frontal attack in the 1980s and by the late 1990s, Keynesians, like the Scots in the 14th century-had become a diverse set of clans, often fighting among themselves and meeting each other clandestinely in various retrospective conferences such as the one where these papers were first presented. ${ }^{3}$

The demise of functional finance in policy

The rules of functional finance lost favor as a basis for policy because, empirically, they did not seem to lead to the desired state of the economy. Specifically, initial interpretation of the rules of functional finance concluded that the target rate of unemployment should be approximately 3 per cent. This was based on an implicit assumption that inflation would only become a problem at lower rates of unemployment. If unemployment rose above 3 per cent, the government should increase spending or lower taxes; if unemployment fell below 3 per cent, the government should increase taxes or lower spending. So too with the interest rate: if unemployment were above 3 per cent, the government should lower interest rates by increasing the money supply. Conversely if unemployment were below 3 per cent, the government should raise interest rates by decreasing the money supply.

It is important to note that the initial interpretation of a 3 per cent target rate of unemployment is not inherent in the functional finance rules. Rule 1. does not state what is meant by excessive unemployment. Nor does it state what to do if both a zero level of inflation and the desired rate of unemployment cannot be achieved. Thus, depending on how they are interpreted, the rules of functional finance can be compatible with many different types of government spending and taxing rules.

As the rules were interpreted, however, they became synonymous with significant deficit spending. Functional finance was seen as having an expansionary and inflationary policy bias. As modern Keynesians gave up their belief that they could specify the desired inflation and unemployment rates independently of the actual functioning of the economy, they simultaneously abandoned the functional finance policy prescriptions. As a result, in the 1990s, the rules of functional finance are little discussed. This is unfortunate because there is still much sense in the rules. Specifically they lead to the policy questions of why a 3 per cent unemployment rate is inconsistent with a stable price level and whether institutions could be changed to make it consistent. Only a few outspoken Keynesian economists-Robert Eisner and Bill Vickrey come to mind-have been vocal in pointing out the problems with the new emphasis on balanced budgets.

Actually the giving up of the rules of functional finance by policy makers occurs much more in words than in deeds. Despite what central bankers may say their policy is, and despite the rhetoric of policy oriented macro economists, the actual policy reaction to recessions is now quite different than it was in pre-Keynesian times. When presenting fiscal policy to voters, governments talk about balanced budgets; but the benefits of government deficits in a recession are recognized. ${ }^{4}$ 
At times, however, the policy rhetoric of modern macroeconomics is written down as a framework for policy, as in the structure of the new European Monetary Union where member countries are required to have budget deficits no larger than 3 per cent regardless of the state of the economy. Such a requirement precludes the use of functional finance rules and thus could present serious problems for the European Union. My suspicion is that ways around these rules will be found because, while the rhetoric of functional finance is not used, the lessons of functional finance-you don't try to reduce the deficit when the economy is heading into a recession - are still understood by most policy makers (even though they are not understood by many young theoretical macro economists).

The demise of functional finance in theory

Somewhat less important from society's standpoint, but more interesting from the standpoint of most economists, is the demise of functional finance on the theoretical front. This decline is closely tied to major developments in theoretical macro - the rise to power of neoKeynesianism, the micro-foundations revolution, the New Classical revolution and the New Keynesian flash in the journals. A brief review of these developments will explain how the theoretical demise of functional finance came about.

\section{From Keynesian to neoKeynesian macroeconomics}

The seeds of the theoretical loss of favor of functional finance were sown early in the Keynesian revolution when the formal development of the Keynesian model was tied to the Walrasian unique equilibrium general equilibrium model. This grafting of the two lines of research led to neoKeynesian economics that placed Keynesian economics in a unique equilibrium aggregate framework. This Walrasian framework was devoid of the institutional characteristics that underlay Keynesian economic reasoning. It was at that point that Keynesian economics entered a theoretical end-play leading, ultimately, to its almost total demise.

One of the aspects of the decision to structure the Keynesian argument within a Walrasian model was the long, unproductive debate about the role of wage and price level flexibility in macro. Having, in my decadent youth, taken part in some of that debate, I try now to avoid it entirely. In reality wages and prices are not, and cannot be, perfectly flexible in any institutional structure that resembles our own and thus that debate about price level flexibility is irrelevant for policy and for understanding how our real world economy works. ${ }^{5}$

My basic working premise is that our type of monetary system requires a relatively stable price level. Financial institutions and contracts are based on the prescription of reasonable price level stability and cannot operate efficiently without far more stability than is required by any formal, theoretical, Classical price level adjustment story. ${ }^{6}$ Unexpected changes in the price level bring about changes in the terms of contracts. Since full price-level-contingent contracts are too complicated to design, the very functioning of our economic system relies upon the price level not varying 'too much.' Since the Walrasian theory assumes a functioning economy, to the degree that the models require significant price level flexibility to maintain equilibrium, they embody a fundamental inconsistency. 
Effects of variations in the price level are asymmetric; inflation can actually provide a temporary stimulus as wealth is redistributed from creditors to debtors who include most entrepreneurs. Deflation, however, will redistribute money from debtors to creditors and can undermine the financial stability of many businesses. If the government does not step in as that happens, the economy, its institutional structure undermined, will fall apart. ${ }^{7}$ A significant fall in the price level as required by modern adjustment mechanisms that underlie textbook macro models and give rise to what those texts call 'the aggregate demand curve,' would undermine existing financial institutions and, by extension, the institutional structure underlying our economy. As Keynes said, 'Having regard to human nature and our institutions it can only be a foolish person who would prefer a flexible wage policy to a flexible money policy.' Such common sense is not based on money illusion. It is based upon our institutions' dependence on a relatively fixed price level and the need to maintain institutions as a foundation to the existence of markets. ${ }^{8}$

Why were the neoKeynesians willing to agree to such a synthesis that theoretically precluded Keynesian economics? As I argued in The Coming of Keynesianism to America their primary interest was policy; theory for them was something that led to a model with acceptable policy conclusions. The fact that one could develop a model requiring the policy they wanted within a fixed-wage Walrasian structure, led them to accept a synthesis based on that structure in order to avoid unending, and quite irrelevant, arguments with Classicals over logical debating points with little relevance on the checkerboard of real life.

\section{From neoKeynesian to micro foundations}

Like many compromises based on short-run policy concerns, the neoKeynesian compromise had within it the seeds of destruction of neoKeynesian economics. The destruction of neoKeynesianism began with the work in microfoundations that led to the rise of Phelps's and Friedman's concept of the natural rate of unemployment. That microfoundations work changed the name of the theoretical game. It was no longer acceptable to develop comparative static macro models and then talk about how to relate those models to policy. Instead to be taken seriously in macro economic theory, one had to structure one's model within a Walrasian system and relate one's equilibrium concept to a steady state equilibrium framework.

The acceptance of the need for microfoundations had two effects: first, it undermined many of the Keynesian models as being without micro foundations and second, it created a split between long run and short run analyses. The long run domain was given to the Classicals, since wages and prices were assumed flexible in the long run and the neoKeynesians had already agreed that with flexible wages and prices the economy would gravitate to its long run equilibrium. For policy-oriented Keynesian macro economists, these new terms of synthesis were still acceptable, since there was still a short run role for their primary policy concern: stabilization policy. Functional finance was still possible, as long as it was kept to a stabilization role around a predetermined natural rate. However the stage was also set for the next theoretical development in macro that was to undermine neoKeynesian analysis and place it in the dustbin of history. 
From micro foundations to New Classical macro: the rational expectations revolution

The next step in the burial of Keynesian economics was the rational expectations revolution. This hypothesis was first suggested by John Muth in 1961 when, while working on a project on institutions and process in economics, he extended some ideas originating from the Stockholm expectational school. Muth suggested an improvement to the ad hoc method by which expectations were analyzed in discussing price movements. Before Muth's article, the contention was that individuals average past and present prices as predictors of future prices. It was not clear how weights were chosen, nor was there any clarity as to the validity of this entire method. This led Muth to raise two fundamental questions: (1) What kind of information is, in fact, used and how is it processed to estimate future conditions? (2) How can change in expectations be predicted according to alterations in the amount of available information or with a change in the structure of the system?

Muth's answers to these questions were delightfully simple: Assume that since expectations are the informed predictions of future events, they are essentially the same as those that would be derived by the relevant economic theory. This answer became the basis for the rational expectations hypothesis in macro.

There are two things to note about this revolution. The first is that while Muth wrote his paper in 1961 about an individual market, his idea was not taken up because it was felt that its informational requirements in an individual market were too great to be useful in practice. It only became widely used when in 1969 Lucas and Rapping applied it to macro where, ironically, the informational requirements were infinitely more complicated than in an individual market.

The second point to raise about rational expectations is that to call the expectations rational was a marketing coup. The issue had nothing to do with rationality; it had to do with consistency. As Allen Walters (1971) pointed out, Muth's contribution actually concerned modeling. Muth argued, quite reasonably, that it would be desirable for a model to assume that individuals in the model understand that model and base their actions upon that understanding. For unique equilibrium models, this would mean that the model should assume that individuals know the solution to the model and act accordingly. Such expectations would more appropriately be called 'model-consistent expectations.' Muth argued that any model should have the property that its solution be consistent with modeling individual's expectations within that model.

This assumption put neoKeynesians on the floor because it undermined the basis of the compromise they had had with Classical economists. It essentially tied together the long run and the short run and made it so that anything that could happen in the long run would be anticipated in the short run and, therefore, short run policy could not be effective unless based upon real cost differentials.

The result of combining rational expectations with the market clearing assumptions that underlay the neoKeynesian/neoclassical synthesis was the New Classical economics revolution. New Classical economics took rational expectation and used it in conjunction with the Walrasian unique equilibrium model to arrive at the proposition that, assuming competitive markets, if macro policy were irrelevant in the long run it was also irrelevant in the short run. Thus the fact that Keynesian economics had conceded the long run to the Classicals meant that, to be logical, they should also concede the short run. This proposition was much debated; implicit contracts, staggered 
contracts and a variety of nominal and real imperfections were raised by New Keynesians, creating the possibility of some role for stabilization policy in the short run despite rational expectations. But these were rear-guard actions. With the development of rational expectations, neoKeynesian economics as we knew it was essentially theoretically dead.

\section{The rules vs. discretion addendum}

Along with the development of New Classical economics, there was simultaneously the related development of Kydland and Prescott's time-inconsistency argument for rules over discretion. This was used to argue against the short run role for Keynesian policy that still remained. The time inconsistency argument goes as follows: Discretion at each moment in time is the optimal policy; rules are the consistent policy. Following the optimal policy in each time period - following discretion - can lead to dynamic suboptimality and is hence a worse policy than a consistent policy. Ergo, conclude Kydland and Prescott: Rules are preferable to discretion. ${ }^{9}$

They 'prove' their case with mathematics, but they attempt to convince the reader with the following metaphor:

Suppose the socially desirable outcome is not to have houses built in a particular flood plain, but given that they are there, to take certain costly flood-control measures. If the government's policy were not to build the dams and levees needed for flood protection and agents knew this was the case, even if houses were built there, rational agents would not live in the flood plains. But the rational agent knows that if he and others build houses there, the government will take the necessary flood control measures. Consequently in the absence of a law prohibiting the construction of houses in the flood plain, houses are built there and the army corps of engineers subsequently builds the dams and levees.

In this example, building the dam is the optimal policy; not building the dam is the consistent policy; and most people can easily see the problem with following the optimal policy. The time inconsistency argument did not kill neoKeynesian economics - rational expectations had done that. The time inconsistency argument nailed the coffin shut so that neoKeynesians could not rise from the dead.

Beyond New Classical Economics: recent developments and the revival of a theoretical role for functional finance

If the New Classical revolution were the end of the story, functional finance would belong in the dustbin of history. But it does not. The New Classical revolution brought about some serious rethinking about the neoKeynesian/Classical synthesis. Specifically the tying together of Keynesian macroeconomics with Walrasian economics was questioned. ${ }^{10}$ That rethinking sets up the possibility of a more meaningful theoretical macroeconomics in which the rules of functional finance can play a central role in the conception of macro policy.

All of the policy conclusions of the New Classicals are based upon the assumption of the unique equilibrium Walrasian model. If the Walrasian unique 
equilibrium underpinnings are removed, the rug is pulled out from New Classical economics and macroeconomics is thrown into chaos, or at least into complexity, the precise location from which new developments are coming. ${ }^{11}$ Why has it taken so long for economics to face up to this complexity? It is an interesting question about the sociology of the profession, but I think Joseph Schumpeter spelled out the central reason when he wrote:

Multiple equilibria are not necessarily useless, but from the standpoint of any exact science the existence of a uniquely determined equilibrium is, of course, of the utmost importance, even if proof has to be purchased at the price of very restrictive assumptions; without any possibility of proving the existence of (a) uniquely determined equilibrium - or at all events, of a small number of possible equilibria - at however high a level of abstraction, a field of phenomena is really a chaos that is not under analytical control. (1954)

Since economics wanted to be and still wants to be an 'exact science,' it had to assume away the possibility of multiple equilibria. In doing so the intuitive logic that supports multiple equilibria is also assumed away. Standard economics simply avoided such issues. Recently, however, with the development of the science of complexity and major developments in non-linear systems theory, more and more economists have been willing to give up the sense of economics as an 'exact science' and, happily, see it as an intuitively sensible, empirical science and deal seriously with the economy's complexity. Herein lies, for me, the further development of macro theory and the potential resurrection of the rules of functional finance within theory. They are institutionally specific rules that embody important lessons from history. They are not theoretically derived and immutable rules.

Within multiple equilibria models there is a potential theoretical role for both monetary and fiscal policy. Although economists are a long way from formally specifying that role, it is possible to specify it informally and to outline the general argument for functional finance in a complex multiple-equilibria world. Functional finance is a method of affecting the equilibrium-selection mechanism so that the economy chooses a more desirable equilibrium. Before I turn to this issue, let me discuss briefly how multiple- equilibria theory undermines the central tenets of New Classical economics.

Multiple equilibria and rational expectations

As I stated above, rational expectations are really model-consistent expectations. If one has a multiple equilibria model, where many outcomes are possible, then just about any set of expectations consistent with one of those potential equilibria is possible. ${ }^{12}$ Used within a multiple equilibria model, there is no inconsistency in the combination of rational expectations and Keynesian economics. Consider Keynes's famous 'expectations' passage:

The social object of skilled investment should be to defeat the dark forces of time and ignorance which develop our future. The actual private object 
of the most skilled investment today is 'to beat the gun' as the Americans so well express it, to outwit the crowd, and to pass the bad, or depreciating, half crown to the other fellow....We have reached the third degree where we devote our intelligence to anticipating what average opinion expects average opinion to be and there are some, I believe, who practice the fourth, fifth, and higher degrees.....

There is no clear evidence from experience that the investment policy which is socially advantageous coincides with that which is most profitable. It needs more intelligence to defeat the forces of time and our ignorance of the future than to beat the gun. Moreover life is not long enough. (Keynes, 1936)

This quotation is completely consistent with individuals holding rational expectations in a multiple equilibria world. Initially, however, macro economists, tied up in a Walrasian unique equilibrium model, did not see this.

With multiple equilibria the long run and the short run are interconnected but neither dominates the other. Short run considerations play a role in choosing which long run equilibrium we arrive at and, hence, short run policy can affect the long run equilibrium. As a practical matter, since many of the long run paths are unknowable, practical policy will often focus on the short run. After all, as Lerner said, the long run is simply a collection of ongoing short runs and, in the long run, we find ourselves in another short run. In a multiple equilibrium model, policy is not only affecting stabilization around a stable long run path; policy is also affecting the economy's choice as to which of the multiple growth paths to take.

Time-inconsistency in a complex economic environment

Let me now turn to the time-inconsistency argument. The problem with the argument is not with the mathematical proof - that is almost logically trivial. The problem is with the interpretation Kydland and Prescott and others, such as Robert Barro, give to it. These New Classical economists equate rules with consistent policies and discretionary action with optimal policy, concluding that rules are preferable to discretion because of problems that develop if people can expect government to follow an optimal policy.

While theirs is one possible definition of rules, it is not a meaningful one when there is uncertainty about the future in a complex, multiple equilibria environment. A rule in the Kydland-Prescott definition involves full specification of what will be done in every possible contingency; their rules are what I would call 'full contingency rules.' Given this definition, any proof of the superiority of rules over discretion is trivial. The very definition of rules includes all possible discretionary action. It is totally possible within the Kydland-Prescott definition of rules to say that the rule that the government should follow is to act optimally, subject to a well-specified social welfare function. This rule is not the rule that most individuals consider when they speak of rules. Most definitions of rules are of limited contingency and there is no a priori case for the superiority of limited contingency rules over discretion.

My objection to Kydland and Prescott is that they jump from their mathematics demonstrating the superiority of a full contingency rule to a discussion of policy that suggests a very simple monetary rule. That a simple monetary growth rule is incorrect can be seen in the following example: 
Say the rule states that the government will increase the money supply by 3 per cent regardless of circumstances. Then, in the second period, half the world sinks into the sea because of some shift in the underlying geostructure of the earth. Most economists would argue that the money supply should be reduced to prevent inflation in such a situation but, if the simple 3 per cent rule is followed, that cannot be done if the rule is to be upheld.

Rejection of the Kydland and Prescott argument does not imply that discretion is preferable to rules only that one cannot a priori prove the superiority of either discretion or rules in an operational sense. Specific rules and specific discretionary actions must be compared by calculating the expected loss function under both. The steady state rule will usually be followed, but the possibility of discretionary actions remains for sufficiently unanticipated contingencies that are optimal to build into the rules. So time inconsistency does not theoretically preclude functional finance - nor any policy - in a complicated world where all contingencies cannot be specified.

Multiple equilibria and functional finance

Let me now turn to the potential theoretical role of functional finance in a multipleequilibria economy. Above I stated that functional finance's theoretical role was to influence the equilibrium selection process of the economy. But cannot the same questions be asked as was asked by the Classicals in a unique equilibrium world?: Why should the government have any role in guiding the economy to an equilibrium? Why doesn't the same '\$20 lying on the pavement' argument work for multiple-equilibria economies? The answer to these questions is a simple one: With multiple equilibria there is no presumption of global optimality of the equilibrium chosen by the market. Everyone can know of the existence of a preferable equilibrium but may not be able to achieve it by private actions. We can only say something about that question when we have a theory of equilibria selection mechanisms. Currently we have none. Thus there should be no general presumption that the private economy, given its institutions, arrives at an equilibrium preferable to one achieved with government guidance.

Another way to express that same idea is to say that the ' $\$ 20$ on the pavement' argument concerns profit while the multiple equilibria argument concerns rent. Competition eliminates profit; it does not eliminate rent. If one can show empirically that government has a comparative advantage in adjusting to short-run fluctuations, then it can have a positive effect even though there is no potential profit available to private individuals. Here enters Lerner's and my macroeconomic externality argument. The effects of individual decisions on the aggregate level of spending and inflation are too small for individuals to take into account separately; it only makes sense for people to take those effects into account collectively. Since people have collectively organized through government already, the logical agent to internalize those externalities is government. Thus the reason that there is a potential role for government is that comparative advantage implies that rent, not profit, exists.

Notice I have said 'potential role.' Theory will not prove or disprove a role for government; it simply provides a framework for thinking about the issue. Built into the rules of functional finance is the implicit assumption that government has a comparative 
advantage in achieving steady state stabilization. Keynes and Lerner gave plausible reasons why government did have a comparative advantage; they did not prove it did have a comparative advantage. That position can only come from historical observation.

In my view, the past 60 years have shown both the limits and strengths of functional finance. Its strength is in providing a guide for handling major swings in aggregate demand such as those caused by the financial crises we recently saw in Asia. (This is what Axel Leijonhufvud refers to as 'out of the corridor' swings.) Even when functional finance is not used, its role is central to the efficient functioning of our economy; it is the expectation that government functional finance policy will be used when crises occur that gives stability to our economy, keeping it in the corridor. This allows the economy to expand much more than it otherwise would and thus provides a necessary foundation for growth. This means that the expectations of the policy often make it unnecessary for the policy to be used.

But history has also shown us the limits of functional finance. The first limit of functional finance policy involves fine tuning. Government policy is not a finely tuned instrument-Lerner's steering wheel analogy is misleading; government policy is more like steering a 200,000 ton super tanker that takes 20 miles to make a full turn. This limitation is now generally agreed upon.

The second limit involves the level of unemployment that can be aimed for given existing institutions. The initial interpretation that 3 per cent unemployment could be the target has proven far too ambitious, and it now seems clear that there is a range of between 3 and 8 per cent unemployment in the United States where the policy directives flowing from Lerner's functional finance rules are ambiguous. Within this range, inflation and unemployment occur simultaneously and therefore functional finance gives two alternative policy directives.

The fourth rule of functional finance

Lerner quickly recognized the problem, at least as it related to the problems of inflation and unemployment, and started early on to revise his theory of macro to directly take into account the possibility of multiple equilibria. He did this in two ways: (1) He distinguished two equilibria the economy could achieve - a high level and a low level of full employment; and (2), he specified a new form of inflation - sellers' inflation-which operated as a separate phenomenon, quite apart from demand pressures. Depending on how sellers' inflation was dealt with, there could be either high full employment or low full employment. Sellers' inflation resulted from existing institutional realities; it was not part of the perfectly competitive model, but Lerner was quite willing to relinquish the perfectly competitive model when he found that it did not fit reality.

His reaction to the ambiguous range was not the conventional one. Conventional wisdom has been to forget the unemployment target and simply aim for the inflation target. Thus the standard rules have government concerned only with inflation under the belief that the economy will gravitate to some long run equilibrium that is independent of government policy. For Lerner inflation that occurred before 3 per cent unemployment was a product of faulty institutions, not a problem inherent in markets. Thus he refused to accept that the target level of unemployment should be raised to whatever level required to stop inflation. 
Lerner found the implications of sellers' inflation so important that, beginning in the 1960s, he changed his research program to center on finding cures for sellers' inflation. Initially he toyed with various administrative wage and price control policies, but he found those lacking and soon gave them up. He replaced them, first, with a tax based incomes policy and ultimately, a market based incomes policy in which property rights in prices are set and individuals have to buy the right to change prices from others who change their price in the opposite direction. It was this idea that formed the basis of our market anti inflation (MAP) book. (Lerner and Colander 1980) Under MAP, rights in value added prices would be tradable so that any firm wanting to change its nominal price would have to make a trade with another firm that wanted to change its nominal price in the opposite direction. Thus, by law, the average price level would be constant but relative prices would be free to change.

Three features of MAP should be pointed out. First, it is a totally market oriented plan. Second, practically, it is implemented through a value added per unit input concept not an output price concept. While there are measurement problems with both capital and labor input, they are far less severe than with output prices. Moreover this measurement assigns the property rights of general productivity increases to the consumer, not to the producer. To emphasize this point, Lerner and I have called MAP a form of synthetic competition. Third, MAP credits will have a zero price in a purely competitive society with no inflationary tendencies, yet most economists' intuition fails to lead them to that view.

To integrate the necessity of dealing with the institutional problem of sellers' inflation by changing institutions rather than accepting whatever unemployment was required to stop inflation, Lerner and I arrived at a modification of the rules of functional finance. Specifically, we added a fourth rule: 'The government must establish policies which stabilize the price level and coordinate both the money supply rule and the aggregate total spending rule with this stable price level at the unemployment level it prefers. ${ }^{13}$ With this fourth rule the rules of functional finance can once again be relevant to modern economic problems.

\section{Conclusion}

In conclusion, let me make some general comments about Lerner's contribution to economics. As Keynes suggested in the letter I quoted at the beginning of the paper, Lerner operated in two different worlds - one of micro and one of macro. Lerner is best known for his contribution to micro economics, specifically his contribution to setting up the foundations of modern welfare economics in the Economics of Control. That contribution is still seen as major and his contribution in macro is seen as minor. I suggest that it should be precisely the opposite. True he did make contributions to unique equilibrium general equilibrium theory, but that theory is not especially interesting. His major contribution is in macro where he spelled out some important operating rules of thumb - functional finance - that can serve as a solid guide to policy makers.

When commenting on the difficulties of the first three rules of functional finance he writes:

These problems... will make life difficult for the administrators of the economy....[B] ut there is no reason for supposing that life will be any more 
difficult than in any other financial system which does not give the society the benefits of Functional Finance....Functional Finance will not inaugurate a problemless world. Life will not be effortless. There will still be struggles and conflicts and defeats. ...But it is an important step forward.

The conflicts and struggles for functional finance have been much more difficult than Lerner expected they would be, but if we make the same deal with policy makers today that Keynes wanted to make with Treasury in the 1940s, I think functional finance can once again move to center stage in discussions of macro policy.

Notes

1. The complete letter is reprinted in Colander and Landreth, The Coming of Keynesianism to America (1996).

2. See Colander, 'Was Keynes a Lernerian?' (1984) for a discussion of this issue.

3. The much touted new principles textbook by the 'New Keynesian,' Greg Mankiw, goes so far as to push Keynes and stabilization policy to an end chapter of the book as something for students to learn as an afterthought to Classical economics.

4. The difference between rhetoric and action is not new. Abba liked to recount the following story of a conversation he had with the president of the Bank of Israel in the corridors of the Treasury in Jerusalem. The president came up to him and said, 'Professor Lerner, once more the government is pressing me to create more money, but I shall resist it till the last ditch.' To which Abba's answer was, 'I see you're getting ready for the last ditch.' Abba concluded the story by pointing out how the central bank always had to submit to the government's pressure, just as the government had to submit to social (and political) pressure. See Lerner (1979).

5. Lerner shared that view and that is what he meant when he distinguished instantaneous price adjustment from fast, but less than instantaneous, price adjustment.

6. The formal stories rely on wealth effects, international effects and Keynes effects. There are also informal stories that are much more intuitively plausible, but these are not part of the formal system and are much more like Keynesian economic adjustment stories with a different political twist.

7. This view is not novel to me. As Jim Tobin points out, Irving Fisher suggested that these effects would be significant. However they have been largely ignored in the literature.

8. Elsewhere (Colander 2001) I have argued that the production function must include a coordination variable and the effect that price level flexibility would have on institutional coordination as a necessary analytic aspect of the core model we present to students.

9. This is the New Classical extension of a long-standing debate in economics. The monetarists' argument for rules was an empirical one. They based it on the limited availability of information about the magnitude and timing of monetary effects, emphasizing the lags in recognizing the need for policy changes in the uncertainty in predicting short run effects. The New Classicals-Kydland and Prescott-made a stronger claim: that the superiority of rules over discretion is a deductive truth, not an empirical argument.

10. I should point out that many Keynesians did not accept the neoKeynesian position. Various groups, such as Post Keynesians, Clowerians and many others, refused to 
accept the basic neoKeynesian position. But their view was in the minority and did not show up in the textbooks. Thus when the 'grandsons' learned Keynesian economics, they learned neoKeyesian economics.

11. Complexity refers to the work of individuals associated with the Santa Fe Institute; they are attempting to model macroeconomics following their intuition, rather than letting the mathematical modeling requirements guide their assumptions. The result is extraordinarily complex models that come to no specific policy conclusion, at least not yet. This, to me, is a significant result; when one models the economy reasonably, one does not come to any specific macro policy conclusions. Policy conclusions are only arrived at when one combines theory with a knowledge of institutions in the art of economics. The world is too complex, given the current state of our understanding of the economy, to draw definitive policy conclusions from a model. See Colander (1997). 12. Generally the formal models that are workable on this level are game-theoretic models; see the work of John Bryant (1996) or Russell Cooper (1999).

13. For the arguments for this rule see Colander (1979). 
Bibliography

Bryant, John (1996), "Team Coordination Problems and Macroeconomic Models" in Colander (ed.), Beyond Microfoundations: Post Walrasian Macroeconomics, Cambridge: Cambridge University Press.

Colander, David (1979), "Rationality, Expectations and Functional Finance," in James Gapinski (ed.), Essays in Post Keynesian Inflation, Cambridge MA: Ballinger. Literature. (December, 1984), "Was Keynes a Lernerian?" Journal of Economic (ed.) (1986), Incentive Based Incomes Policies, Cambridge MA: Ballinger. (2001), "A Post Walrasian Explanation of Wage and Price Inflexibility and a Keynesian Unemployment Equilibrium System” in Mark Setterfield (ed.), Essays in Honour of John Cornwall, New York: Macmillan.

Colander, David and Harry Landreth (1996) The Coming of Keynesianism to America, Alsershot,UK and Brookfield, US: Edward Elgar.

Cooper, Russell (1999), Coordination Games: Complementarities and Macroeconomics, Cambridge: Cambridge University Press.

Keynes, John Maynard (27 September 1944), personal correspondence to Abba Lerner.

Keynes, John Maynard (1936), The General Theory of Employment, Interest, and Money, London: Macmillan.

Kydland, Fynn and Prescott (June1977), 'Rules Rather than Discretion: The Inconsistency of Optimal Plans,' Journal of Political Economy.

Lerner, Abba (June 1941), 'The Economic Steering Wheel,' The University Review. (1944), The Economics of Control, New York: Macmillan. (1951), The Economics of Employment, New York: McGraw Hill.

Lerner, Abba, and David Colander (1980), MAP: A Market Anti-Inflation Plan, New York: Harcourt Brace Jovanovich.

Schumpeter, Joseph (1954), History of Economic Thought, New York: Oxford University Press.

Walters, Alan (1971), "Consistent Expectations, Distributed Lags, and the Quantity Theory," Economic Journal. 